\title{
Analisis Strategis dan Kunci Keberhasilan Badan Pengembangan Sumber Daya Manusia (BPSDM) Provinsi Jambi
}

\author{
Lailatul Isnaini, Musfarita Affiani \\ Dosen/Widyaiswara BPSDM Prov. Jambi \\ Correspondence email: anand.isnaini@gmail.com, Yeyen.gr@gmail.com
}

\begin{abstract}
This paper aims to determine 1) the internal environment BPSDM Prov. Jambi, 2) external environment BPSDM Prov. Jambi, and 3) what strategic alternatives that could be taken after the change in nomenclature BPSDM Prov. Jambi. The main method of this article is a review of the relevant literature and documentation were analyzed using analysis of internal factors (Internal Factor Analysis Summary), the analysis of external factors (External Factor Analysis Summary) and SWOT analysis.
\end{abstract}

Keywords: Prov. BPSDM Jambi, external environment analysis, internal environment analysis, SWOT analysis.

\section{PENDAHULUAN}

Besarnya tantangan sebagai konsekuensi dari adanya era reformasi dan peningkatan persaingan di era globalisasi, tuntutan masyarakat akan pelayanan prima, serta kurangnya sumberdaya aparatur yang memenuhi persyaratan kualitas, mendorong Badan Pengembangan Sumber Daya Manusia (BPSDM) Provinsi Jambi mempersiapkan diri dan berupaya menangkap peluang-peluang baru. Untuk tetap eksis dan unggul dalam suatu tahapan yang kosisten, konsukuen dan berkelanjutan, maka harus meningkatan akuntabilitas kinerja yang berorientasi pada pencapaian hasil dan manfaat. Semuanya akan terwujud apabila terjadi keseimbangan kepentingan antara semua pihak (stakeholders) dalam rangka mencapai tujuan organisasi tersebut. Perlu identifikasi faktor-faktor stratejik lingkungan eksternal dan internal Untuk mengetahui dan mengembangkan potensi BPSDM Provinsi Jambi kedepan, dan menggunakan analisis SWOT untuk mengetahui kunci keberhasilannya. Analisis ini dapat membantu organisasi menyusun suatu rencana untuk mencapai tujuan, baik itu tujuan jangka pendek maupun tujuan jangka panjang. Kegiatan paling penting dalam prose analisis adalah mendalami seluruh informsi yang terdapat pada suatu kasus, menganalisis situasi untuk mengetahui isu apa yang terjadi, dan memutuskan tindakan apa yang harus segera dilakukan untuk memecahkan masalah (Rangkuti, 2015). Analisis mengarah pada suatu pilihan yang sifatnya stratejik. Selanjutnya, analisis mungkin menunjukkan semua alternatif yang dapat ditempuh untuk mengambil suatu keputusan oleh pemimpin puncak (Siagian, 2005).

\section{Literature Review}

\section{BPSDM Provinsi Jambi.}

Terbitnya Peraturan Gubernur Nomor 59 Tahun 2016 tentang kedudukan, susunan organisasi, tugas dan fungsi, serta tata kerja Badan Pengembangan Sumber Daya Manusia Provinsi Jambi, merupakan salah satu komitmen pemerintah, serta sebagai strategi organisasi dalam rangka meningkatkan sumber daya aparatur pemerintah daerah. Sebelum adanya peraturan tersebut organisasi ini adalah sebuah Badan Pendidikan dan Pelatihan Daerah Provinsi Jambi, yang tugasnya menyelenggarakan pendidikan dan pelatihan aparatur dilingkungan pemerintah provinsi Jambi.

Badan Pengembangan Sumber Daya Manusia Provinsi Jambi, dalam menjalankan tugas pokok dan fungsinya bertujuan untuk mencapai visi, yaitu mewujudkan aparatur sipil negara yang memiliki kompetensi, dedikasi, dan integritas. Memiliki kompetensi artinya karakteristik dan kemampuan kerja yang mencakup aspek pengetahuan, keterampilan, dan sikap sesuai tugas dan fungsi jabatan. Dedikasi artinya pencurahan tenaga, pikiran, dan waktu demi keberhasilan tujuan organisasi sebagai wujud daari pengabdian. Integritas artinya ketaatan kemampuan bertindak secara konsisten untuk merasa memiliki sesuai dengan nilai-nilai hukum, sosial dan agama. Untuk mewujudkan visi tersebut, Badan Pengembangan Sumber Daya Manusia Provinsi Jambi menetapkan misi sebagai berikut: 1) menyelenggarakan pengembangan sumber daya manusia aparatur berbasis kompetensi yang berdaya guna berhasil guna;2) mewujudkan kelembagaan 
pengembangan sumber daya manusia aparatur yang memadai, efektif, efisien dan akuntanbel. (Adisetiawan, 2016)

Sebagai lembaga teknis daerah, Badan Pengembangan Sumber Daya Manusia Provinsi Jambi memiliki fungsi dan peran strategis. Pertama, lembaga teknis merupakan sebuah support system satuan kerja pemerintah daerah secara secara keseluruhan. Bentuk dukungan tersebut adalah mendidik dan melatih aparatur pemerintah provinsi Jambi agar dapat menjadi sumber daya utama dalam proses-proses pembangunan provinsi Jambi. Kedua, Badan Pengembangan Sumber Daya Manusia Provinsi Jambi memiliki tugas yang terkait dengan peningkatan kompetensi sumber daya manusia aparatur, yang merupakan sumber daya utama dalam menggerakkan program dan kegiatan yang telah dicanangkan. Pelaksanaan Program dan kegiatan tersebut adalah menyelenggarakan pengembangan kompetensi dilingkungan pemerintah Provinsi dan Kabupaten/Kota, dan menyelenggarakan sertifikasi kompetensi di lingkungan pemerintah Provinsi/Kabupaten/Kota. Ketersediaan sumber daya aparatur yang profesional mutlak dibutuhkan dalam rangka mewujudkan visi dan misi organisasi atau visi dan misi pemerintah daerah. (Adisetiawan, 2017)

\section{Analisis Lingkungan Internal}

Lingkungan internal organisasi adalah semua yang ada dalam tubuh organisasi itu sendiri, dari pimpinan sampai bawahan, yang saling bekerjasama untuk mencapai tujuan organisasi (Maisah, 2016). Lingkungan internal adalah proses dimana perencanaan strategi mengkaji faktor internal perusahaan untuk kekuatan dan kelemahan sehingga dapat mengelola peluang secara efektif dan menghadapi ancaman yang terdapat dalam lingkungan organisasi tersebut (Jauch dan Glueck, 1997).

Analisis lingkungan internal perusahaan mencakup sumber daya, kemampuan dan kompetensi yang dimiliki (Barney., et al: 2012; Thomson \& Strickland, 2010). Pearce dan Robinson (2013) membagi sumber daya menjadi 3 (tiga), yaitu: (1) Aset yang terlihat (aset berwujud) meliputi fasilitas produksi, bahan baku, sumber keuangan, dan komputer; (2) aset tidak berwujud (aset tidak berwujud) termasuk dalam merek, reputasi, usaha moral, pengetahuan teknis, hak paten, merek dagang, dan akumulasi pengalaman perusahaan; (3) Kemampuan organisasi, keterampilan dan kemampuan menggabungkan aset, manusia, dan proses yang dapat digunakan oleh perusahaan untuk mengubah input menjadi output. Cara lain yang bagus untuk menganalisis kekuatan dan kelemahan suatu organisasi. Pearce dan Robinson (2013) memperkenalkan metode analisis internal yang dikenal dengan analisis value chain (value chain).

Beberapa unsur yang dianalisis dalam menganalisa lingkungan internal yaitu: 1) sumber daya perusahaan adalah segala sesuatu yang dapat dimanfaatkan oleh perusahaan guna mendukung perkembangan perusahaan, seperti sumber daya manusia, sumber daya produksi, sumber daya keuangan, pemasaran serta penelitian dan pengembangan. Untuk menciptakan keunggulan bersaing apalagi yang berkesinambungan, manajemen harus mampu menggabungkan seluruh sumber daya yang dimiliki sehingga menghasilkan kemampuan yang akhirnya menjadi sumber bagi kompetensi inti. Selanjutnya sumber daya perusahaan ini dibedakan menjadi dua yaitu sumber daya berwujud dan tidak berwujud; 2) Kapabilitas, kapabilitas adalah suatu kombinasi untuk sumber daya yang dimiliki perusahaan baik yang berwujud atau tidak berwujud. Keahlian dan pengetahuan manusia merupakan hal yang paling signifikan dan merupakan segala akar bagi keunggulan bersaing dan merupakan dasar utama bagi kemampuan perusahaan yang seharusnya dimiliki para karyawan. Lestari (2011) kapabilitas adalah kapasitas perusahaan untuk menggunakan sumber daya yang diintegrasikan dengan tujuan untuk mencapai tujuan akhir yang diinginkan. 3) Kompetensi inti adalah sumber daya dan kapabilitas yang menjadi sumber keunggulan kompetitif bagi perusahaan melebihi pesaingnya. Sumber daya dan kapabilitas adalah dua hal yang sangat diperlukan dalam proses implementasi strategi yang selanjutnya mewujudkan nilai yang dapat meningkatkan efektivitas dan efisiensi perusahaan. Meskipun ada banyak cara untuk menganalisa lingkungan internal, cara termudah untuk mengamati dan menganalisa lingkungan internal adalah melalui analisis fungsional (Thomas L. Wheelen \& J David Hunger, 2012).

Analisis lingkungan internal adalah proses di mana perencana strategi mengkaji pemasaran dan distribusi perusahaan, penelitian dan pengembangan, produksi dan operasi, sumber daya dan karyawan perusahaan, serta faktor keuangan dan akuntansi untuk menentukan di mana perusahaan mempunyai 
kemampuan yang penting sehingga perusahaan memanfaatkan peluang dengan cara yang paling efektif dan dapat menangani ancaman di dalam lingkunan (Glueck dan Jauch, 1998).

Pendapat di atas, maka dapat disimpulkan bahwa faktor-faktor internal terdiri dari :

a. Faktor Pemasaran, Faktor pemasaran terdiri dari bauran pemasaran yang berisi product, promotion, place, and price, di mana dari masing-masing aspek dianalisis untuk mengetahui kekuatan dan kelemahan perusahaan.

b. Faktor Keuangan dan Akuntansi, Merupakan faktor yang berhubungan dengan keadaan keuangan suatu perusahaan terutama untuk menentukan apakah perusahaan tersebut mampu melaksanakan strategi tertentu, atau apakah mereka dianjurkan untuk melaksanakannya. Faktor yang dianalisa biasanya berupa neraca dan laporan rugi-laba.

c. Faktor Produksi, Operasi, dan Teknik, Merupakan kegiatan perusahaan dalam menghasilkan produk dan jasa. Dalam faktor ini efektifitas dan efisiensi proses operasi dan produksi dapat menghemat biaya dan meningkatkan produktifitas, sehingga faktor ini penting untuk mengetahui kekuatan dan kelemahan perusahaan.

d. Faktor Sumber Daya Manusia, Menyajikan serangkaian faktor sumber daya dan karyawan perusahaan yang dapat memberikan keunggulan bersaing bagi perusahaan. Hal ini dapat dilihat dari kualitas karyawannya yang ditinjau dari tingkat pendidikan, kesejahteraan karyawan, sistem penggajian, sistem perekrutan dan pengembangan karyawan.

\section{Analisis Lingkungan Eksternal}

Lingkungan eksternal terdiri dari variabel-variabel peluang dan tantangan yang berada diluar organisasi dan tidak dapat dikontrol oleh manajemen. Lingkungan eksternal dapat berupa kekuatan umum dan tren dalam keseluruhan lingkungan sosial atau khusus dalam operasi organisasi (lingkungan tugas) (Maesah, 2016). Keberhasilan organisasi pada tingkat dominan ditentukan oleh kedalaman pengenalan manajemen tentang segala ramifikasi interaksi antara organisasi dan lingkungan eksternalnya, baik yang sifatnya positif maupun yang bersifat negatif (Siagian, 2005). Pengenalan lingkungan eksternal secara tepat semakin penting karena: 1) Jumlah faktor yang berpengaruh itu tidak pernah konstan melainkan selalu berubah; dan 2) Itensitas dampaknya beraneka ragam. Ada faktor eksternal yang merupakan kejutan yang tidak dapat diperhitungkan sebelumnya betapapun cermatnya analisis SWOT dilakukan, kondisi eksternal itu berada diluar kemampuan organisasi untuk mengendalikannya (Siagian, 2005).

Lingkungan eksternal adalah faktor-faktor di luar perusahaan yang berpotensi mempengaruhi perusahaan. Banyak Perusahaan sekarang bersaing masuk Pasar global, tidak hanya di pasar domestik. Perubahan dalam teknologi dan peningkatan kemampuan untuk memperoleh dan memprosesInformasi membutuhkan implementasi dan persaingan. Tanggapan lebih tepat waktu dan efektif. Kebijakan dan hukum pemerintah mempengaruhi dan menggariskan pilihan perusahaan dimana dan bagaimana mereka berkompetisi. Perusahaan harus waspada dan menyadari dampak dari kenyataan lingkungan ini, sehingga bisa menjadi aktor yang efektif dalam ekonomi global. Di Organisasi yang bersaing strategis, pemilik/Manajer perusahaan akan mencari pola yang bisa membantu mereka memahami lingkungan eksternal mereka, dan ini mungkin berbeda dengan apa yang mereka harapkan. Pengambil keputusan penting memiliki pemahaman tentang posisi kompetitif perusahaan.

Teori manajemen strategik mengatakan faktor-faktor yang mempengaruhi lingkungan eksternal dapat dikategorikan sebagai faktor eksternal jauh dan faktor eksternal dekat. Faktor-faktor eksternal disebut jauh karena faktor-faktor tersebut bersumber dari diluar organisasi. Dan biasanya terlepas dari situasi operasional yang dihadapi oleh perusahaan yang bersangkutan, akan tetapi mempunyai dampak pada proses manajerial dan operasional dalam organisasi tersebut. Faktor-faktor lingkungan eksternal yang jauh meliputi faktorfaktor ekonomi, politik, sosial, tehnologi dan industri (Siagian, 2005).

Faktor politik menentukan parameter hukum dan aturan dimana perusahaan harus beroperasi. Faktor politik yang berpengaruh kepada perusahaan berupa keputusan perdagangan, undang-undang anti monopoli, pengenaan pajak, penentuan upah minimum, kebijakan polusi, penetapan harga, dan tindakan lain yang bertujuan untuk melindungi karyawan, konsumen, masyarakat, dan lingkungan. Faktor ekonomi berkaitan dengan sifat dan arah perekonomian dimana perusahaan berada. Setiap perusahaan harus mempertimbangkan trend ekonomi pada segmen yang mempengaruhi industrinya karena pola konsumen 
dipengaruhi oleh kemakmuran relatif dari berbagai segmen pasar. Faktor ekonomi yang harus dipantau oleh manajer adalah kecenderungan konsumsi, tingkat pendapatan bersih, ketersediaan kredit, tingkat inflasi serta trend pertumbuhan produk nasional bruto.

Faktor sosial yang mempengaruhi perusahaan meliputi kepercayaan, nilai, sikap, opini, dan gaya hidup masyarakat yang berkembang dari kondisi budaya, ekologi, demografi, agama, pendidikan, dan etnis. Ketika sikap sosial berubah, permintaan akan berbagai jenis pakaian, hiburan, makanan dan bukupun berubah. Kekuatan sosial bersifat dinamis, salah satu perubahan sosial adalah masuknya sejumlah besar wanita kepasar tenaga kerja. Faktor demografi yang penting diperhatikan adalah ukuran populasi, sruktur usia, distribusi geografis, bauran etnis, dan distribusi pendapatan. Dalam menganalisis faktor demografi ini perusahaan harus menganalisis dengan basis global, bukan hanya dengan basis domestik (Michael A. Hit, et. all, 2001).

Faktor Teknologi suatu perusahaan harus menyadari perubahan teknologi yang mungkin mempengaruhi bisnisnya. Kemajuan teknologi dapat menciptakan produk baru, perkembangan produk, serta membuat barang/jasa menjadi cepat usang. Segmen teknologi meliputi Institusi-institusi dan aktivitasaktivitas yang terlibat dalam menciptakan pengetahuan baru dan menerjemahkan pengetahuan itu ke output, produk, proses, dan materi-materi baru. Dengan adanya perubahan teknologi yang begitu cepat, menjadi penting sekali bagi perusahaan untuk mempelajari segmen teknologi dengan cepat dan menyeluruh. Pentingnya usaha-usaha itu ditunjukkan dengan penemuan bahwa perusahaan yang lebih awal mengadopsi teknologi baru sering kali mencapai pangsa pasar yang lebih tinggi dan menghasilkan laba yang lebih tinggi pula. Jadi, para eksekutif harus mengverifikasi bahwa perusahaan mereka secara kontinu memindai lingkungan eksternal untuk mengidentifikasi pengganti potensial dari teknologi yang saat ini sedang digunakan, juga melihat sejauh mana perusahaan dapat mengambil manfaat dari teknologi-teknologi baru tersebut (Michael A. Hit, et. all, 2001).

Faktor-faktor lingkungan eksternal yang dekat berkaitan erat dengan suasana kompetitif yang dihadapi organisasi, dan juga terhadap peluang yang dapat dimanfaatkan untuk perolehan sumber dana dan daya yang diperlukan, serta dalam memasarkan hasil produk yang dihasilkan. Faktor-faktor lingkungan eksternal yang dekat umumnya dapat dikendalikan oleh perusahaan (organisasi) yang bersangkutan. Faktorfaktor lingkungan eksternal yang dekat, antara lain meliputi: kedudukan kompetitif perusahaan (organisasi) yang berangkutan, profil para pelanggan, perilaku pembeli, faktor pemasok, faktor penyandang dana, dan situasi pasaran kerja sebagai faktor lingkungan.

Analisis Lingkungan Eksternal (ALE) berupa pencermatan dan identifikasi terhadap kondisi lingkungan di luar organisasi yang dapat terdiri dari lingkungan ekonomi, teknologi, sosial, budaya, politik, ekologi dan keamanan pencermatan ini akan menghasilkan indikasi menganai peluang (opportunities) dan tantangan (threas) organisasi dalam mewujudkan tujuan dan sasaran organisasi (Engkoswara dan Aan Komariah, 2010). Buchory dan Saladin (2010) mengemukakan bahwa komponen analisis lingkungan eksternal terdiri dari: 1). Scanning, yaitu mengidentifikasi petunjuk awal dari perubahan dan kecenderungan lingkungan; 2). Monitoring, mendeteksi arti melalui observasi terus menerus atas perubahan dan kecenderungan lingkungan.; 3. Forcasting, mengembangkan proyeksi atas hasil yang diantisipasi berdasarkan perubahan dan kecenderungan yang di monitoring;4) Assessing, menentukan waktu dan pentingnya perubahan dan kecenderungan lingkungan untuk strategi perusahaan dan manajemennya.

\section{Analisis SWOT}

Terdapat hubungan penting antara perencanaan strategis yang menggunakan analisis SWOT dengan manajemen organisasi. Kurang memadainya perencanaan akan menimbulkan kesulitan bagi pemimpin dalam menjalani organisasinya, oleh sebab itu perlu sistem rencana strategis dalam proses perencanaan (Ololube, et.,all, 2016). Analisa SWOT adalah suatu cara untuk mengidentifikasi berbagai faktor secara sistematis dalam rangka merumuskan strategi organisasi. Analisa ini didasarkan pada logika dapat memaksimalkan kekuatan (strength) dan peluang (opportunities) namun secara bersamaan dapat meminimalkan kelemahan (weakness) dan ancaman (threats) (Rangkuti, 2015). Analisis SWOT adalah suatu metode perencanaan strategis yang digunakan untuk mengevaluasi kekuatan (Strengths), kelemahan (weaknesses), peluang (opportunities), dan ancaman (threats) dalam suatu lembaga pendidikan (Maisah, 2016). Analisis SWOT membantu organisasi menghadapi tantangan yang berkembang sehingga dapat 
menjaga stabilitas dan meningkatan produktivitas (Osita.,et.,all, 2014). Dengan menggunakan analisis SWOT dimungkinkan untuk menganalisis lingkungan internal dan eksternal dan mengambil keputusan strategis untuk menyelaraskan kekuatan organisasi dengan peluang lingkungan.

Berkaitan dengan analisis SWOT, terdapat dua bidang kajian seperti berikut: Kekuatan (Streng) dan Kelemahan (Weakness) untuk menganalisis tingkat bisnis (perusahaan individual), sedangkan Peluang (Opportunity) dan Hambatan (Threats) digunakan pada tingkatan industri yang akan diterjuninya. Analisis SWOT secara sederhana dipahami sebagai pengujian terhadap kekuatan dan kelemahan internal sebuah organisasi, serta peluang dan ancaman lingkungan eksternalnya. Lebih lanjut dijelaskan analisis SWOT membandingkan antara faktor eksternal peluang (opportunities) dan ancaman (threats) dengan faktor internal kekuatan (strength) dan kelemahan (weaknesses) yang menghasilkan pilihan strategi. Analisis SWOT dapat merupakan instrumen yang ampuh dalam melakukan analisis stratejik, keampuhan tersebut terletak pada kemampuan para penentu strategi perusahan untuk memaksimalkan peranan faktor kekuatan dan pemanfaatan peluang sehingga sekaligus berperan sebagai alat untuk meminimalisasi kelemahan dalam tubuh organisasi, dan menekan dampak ancaman yang tmbul dan harus dihadapi (Rangkuti, 2015).

Metode analisa SWOT dianggap sebagai metode analisa yang paling dasar, berguna untuk melihat suatu topik atau permasalahan dari 4 (empat) sisi yang berbeda. Hasil analisa biasanya adalah arahan atau rekomendasi untuk mempertahankan kekuatan dan menambah keuntungan dari peluang yang ada, sambil mengurangi kekurangan dan menghindari ancaman. Jika digunakan dengan benar, analisa SWOT akan membantu kita untuk melihat sisi-sisi yang terlupakan atau tidak terlihat selama ini. Teknik analisis SWOT pada dasarnya merupakan suatu teknik untuk mengenali berbagai kondisi yang menjadi basis bagi perencanaan strategi (strategic planner)(Rais, 2009). SWOT adalah singkatan dari lingkungan internal Strengths dan Weakneses serta lingkungan eksternal Oppoturnity dan Threats yang dihadapi dunia bisnis. Analisa SWOT mempertimbangkan faktor lingkungan internal strengths dan weakness serta lingkungan eksternal opportunities dan threats yang dihadapi organisasi. Analisa ini membandingkan antara faktor eksternal peluang dan ancaman dengan faktor internal kekuatan dan kelemahan sehingga dari analisis ini dapat diambil suatu keputusan strategi organisasi (Rangkuti, 2015).

\section{Tahapan dalam analisa SWOT:}

a. Pengambilan data yaitu evaluasi faktor eksternal dan internal

b. Analisis yaitu pembuatan matriks internal dan eksternal dan matriks SWOT

c. Pengambilan keputusan.

Pengambilan data dapat dilakukan melalui wawancara ataupun analisis kuantitatif dan cara-cara lain. Tahap berikutnya adalah membuat matriks SWOT hingga terbentuk empat alternatif kemungkinan strategi seperti terlihat dalam Tabel 1 berikut:

\begin{tabular}{|c|c|c|}
\hline \multicolumn{3}{|c|}{$\begin{array}{c}\text { Tabel } 1 \\
\text { Matriks SWOT }\end{array}$} \\
\hline & STRENGTHS $(\mathrm{S})$ & WEAKNESSES $(\mathrm{W})$ \\
\hline \multirow[t]{2}{*}{ OPPORTUNITIES $(\mathrm{O})$} & Strategi SO & Startegi WO \\
\hline & Menciptakan strategi yang menggunakan & Menciptakan strategi yang meminimalkan \\
\hline \multirow[t]{3}{*}{ THREATS $(\mathrm{T})$} & $\begin{array}{l}\text { kekuatan untuk memanfaatkan peluang. } \\
\text { Strategi ST }\end{array}$ & $\begin{array}{l}\text { kelemahan untuk memanfaatkan peluang. } \\
\text { Strategi WT }\end{array}$ \\
\hline & Menciptakan strategi yang menggunakan & Menciptakan strategi yang meminimalkan \\
\hline & kekuatan untuk mengatasi ancaman & kelemahan dan menghindari ancaman \\
\hline
\end{tabular}

Setelah membuat matriks SWOT dan menentukan empat alternatif strategi, manajemen kemudian harus mengambil keputusan dengan merujuk pada strategi yang diperoleh dalam matriks SWOT.

\section{METODE PENELITIAN}

Penelitian ini menggunakan rancangan penelitian deskriptif. Rancangan penelitian ini di gunakan karena mampu menggambarkan analisis lingkungan internal dan eksternal serta strategi apa yang tepat digunakan oleh BPSDM Provinsi Jambi dalam menghadapi persaingan global. Prosedur penelitian menghasilkan data deskriptif berupa kata atau lisan dari orang-orang dan perilaku yang dapat di amati. 
Penelitian ini akan menggambarkan atau memaparkan analisis SWOT dalam penentuan strategi pada BPSDM Provinsi Jambi. Penelitian ini didukung melalui pengumpulan data melalui dokumentasi dan pengamatan (observasi). Objek dalam penelitian ini adalah lingkungan internal dan eksternal organisasi yang akan dikaji dalam variable SWOT, yakni kekuatan, kelemahan, peluang dan ancaman.

Metode pengumpulan data yang digunakan adalah: 1) metode observasi dimana peneliti melakukan pengamatan langsung terhadap BPSDM Provinsi Jambi untuk memperoleh data atau informasi yang dibutuhkan dalam penelitian ini. Fokus pengamatan tertuju pada keunggulan yang dimiliki oleh organisasi, kelemahan yang menjadi faktor penghambat organisasi, peluang dimasa yang akan datang dan ancaman yang akan dihadapi oleh organisasi, 2) metode dokumentasi dimana peneliti melihat dan mempelajari catatan-catatan serta dokumen yang berhubungan dengan gambaran dari organisasi baik visi dan misi, keuangan, dan struktur organisasi. Teknik analisis data yang digunakan dalam penelitian ini adalah:

1) analisis IFAS (Internal Factory Analysis Summary) dimana analisis IFAS digunakan untuk menganalisis lingkungan internal perusahaan, melalui pendekatan fungsional sehingga dapat diidentifikasikan sejauh mana kekuatan dan kelemahan di daerah-daerah fungsional perusahaan, dan juga untuk memberikan suatu basis bagi pengidentifikasian dan pengevaluasian hubungan di antara daerah-daerah tersebut.

2) Analisis EFAS (External Factory Analysis Summary) digunakan untuk menganalisis berbagai hal yang menyangkut persoalan ekonomi, sosial budaya, demografi lingkungan, politik, pemerintahan, hukum, teknologi, informasi tentang persaingan di pasar industri dimana perusahaan itu berada.

\section{HASIL DAN PEMBAHASAN}

\section{Analisis Strategi BPSDM Provvinsi Jambi.}

1. Lingkungan Internal BPSDM Provinsi Jambi, meliputi:

a. Peserta Diklat, peserta Diklat adalah PNS yang dipersiapkan dalam rangka memenuhi persyaratan kompetensi untuk memantapkan tugas-tugas pekerjaan teknis atau manajerial yang terkait dengan pekerjaan Pegawai Negeri Sipil (PNS) yang bersangkutan, sehingga mampu melaksanakan tugas dan tanggung jawabnya secara profesional (LAN RI, 2015). Peserta diklat di BPSDM Provinsi Jambi terdiri dari : Aparatur Sipil Negara lingkup Provinsi Jambi, dan Lingkup kabupaten/kota dalam Provinsi Jambi. Adapun tahapan tahapan pengelolan peserta diklat sebagai berikut: 1) Analisis kebutuhan peserta diklat; 2) Seleksi peserta didik; 3) Rekruitmen peserta diklat; 4) Proses Diklat; 5) Kelulusan; 6) Uji kompetensi; 7) Monitoring Alumni (pasca diklat). Oleh karena itu manajemen pendidikan dan pelatihan bila dilihat dari segi tahapan dalam masa diklat dapat dibagi menjadi tiga tahapan, yaitu, penerimaan peserta, proses pembelajaran klasikal/non klasikal, uji kompetensi (Teknis /fungsional).

b. Tenaga Kependidikan dan asessor

Peraturan Kepala LAN RI No. 43 tahun 2015 menyebutkan bahwa yang dimaksud dengan tenaga pendidik di lingkup lembaga diklat pemerintah adalah widyaiswara. Widyaiswara adalah PNS yang diangkat sebagai pejabat fungsional dengan tugas, wewenang, dan hak untuk melakukan kegiatan dikjartih PNS, evaluasi dan pengembangan diklat pada Lembaga Diklat Pemerintah. Dikjartih adalah proses belajar mengajar dalam diklat baik secara klasikal dan/atau non klasikal. Widyaiswara dapat menyampaikan materi pembelajarannya jika telah mengikuti dan lulus sertifikasi mata diklat yang akan diampunya.

Tabel 2

Jumlah Widyaiswara BPSDM Provinsi Jambi Menurut Jenjang Jabatan

\begin{tabular}{llrrr}
\hline \multicolumn{1}{c}{ No } & \multicolumn{1}{c}{ Jenjang } & Th.2015 & Th. 2016 & Th.2017 \\
\hline 1 & Widyaiswara Ahli Pertama & 2 & 2 & 0 \\
2 & Widyaiswara Ahli Muda & 10 & 8 & 5 \\
3 & Widyaiswara Ahli Madya & 5 & 8 & 10 \\
4 & Widyaiswara Ahli Utama & - & - & - \\
Jumlah & & 17 & 18 & 15 \\
\hline
\end{tabular}

Sumber: BPSDM Prov. Jambi 2018 
Tabel 2 dapat terlihat, sampai dengan tahun 2017 jumlah widyaiswara 18 orang, terdiri dari jenjang; widyaiswara ahli muda 5 orang, widyaiswara ahli madya 10 orang, sedangkan jabatan widyaiswara ahli utama belum ada. Selanjutnya untuk menguji kompentesi Aparatur Sipil Negara, tugas ini dilakukan oleh assesor yang telah bersertifikasi. Tersedia 12 orang asesor di BPSDM Provinsi Jambi.

Tabel 3

Jumlah Jabatan Asesor BPSDM Provinsi Jambi

\begin{tabular}{llrrrr}
\hline \multicolumn{1}{c}{ No } & & Jenjang & Th.2015 & Th. 2016 & Th.2017 \\
\hline 1 & Asessor & & 1 & 14 & 14 \\
2 & Master Asessor & & - & - & - \\
Jumlah & & 1 & 14 & 14 \\
\hline
\end{tabular}

Sumber: BPSDM Prov. Jambi 2018

Tabel 3 diketahui bahwa sampai tahun 2017 jumlah asessor di BPSDM Provinsi Jambi 12 orang, dan belum ada master asessor. Selama tahun 2016 dan 2017 telah dilaksanakan 4 kali asesmen untuk Jabatan Pimpinan Tinggi Provinsi Jambi/Kabupaten, 4 kali asesmen pemetaan jabatan eselon 3 dan eselon 2 Provinsi Jambi/ Kabupaten, dan 4 kali uji kompetensi jabatan fungsional tertentu.

c. Sarana dan Prasarana Diklat

Sarana pendidikan adalah segala sesuatu yang meliputi peralatan dan perlengkapan yang langsung digunakan dalam proses pendidikan dan pelatihan seperti gedung asrama, gedung belajar, ruangan, meja, kursi, alat peraga, LCD dan lain-lain. Sedangkan prasarana semua kompenen yang secara tidak langsung menunjang jalannya proses pembelajaran di lembaga pendidikan tersebut seperti, halaman gedung, tata tertib diklat dan lain-lain. Sarana dan prasarana pendidikan dan pelatihan dalam BPSDM Provinsi Jambi, sebagai berikut: Gedung perkantoran 2 lantai, Gedung/ruang belajar, Aula, Gedung perpustakaan, Asrama VIP, Asrama/barak, dan Rumah Dinas.

d. Kurikulum, Materi diklat dan Proses Belajar Mengajar

Materi dalam kurikulum Diklat teknis dan fungsional yang berkaitan dengan diklat subtantif mengacu pada kurikulum yang disusun oleh BPSDM Kemendagri RI pusat Jakarta dan Lembaga Administrasi Negara RI, sedangkan materi yang berkaitan diklat struktural seperti diklat kepemimpinan dan diklat CPNS mengacu pada kurikulum yang telah ditetapkan oleh Lembaga Administrasi Negara RI. Penyusunan dan pengembangan kurikulum Diklat Teknis harus berpegang kepada kompetensi jabatan, maupun kompetensi yang dibutuhkan terhadap pekerjaan teknis yang menjadi tanggung jawab PNS yang bersangkutan. Kurikulum Diklat Teknis Substantif menekankan pada penguasaan pengetahuan dan atau keterampilan teknis yang berhubungan langsung dengan tugas pokok instansi baik yang berkaitan pekerjaan teknis subtantif, maupun yang berkaitan pemenuhan persyaratan diklat kepemimpinan dan diklat fungsional kurikulum diklat. Diklat Teknis Umum/Administrasi dan Manajemen menekankan penguasaan pengetahuan dan ketrampilan yang bersifat teknis umum/administrasi dan manajemen maupun yang berkaitan pemenuhan persyaratan diklat kepemimpinan dan diklat fungsional. Kurikulum di anggap sebagai salah satu faktor penentu keberhasilan pendidikan dan pelatihan, karena itu perhatian penyelenggara dan widyaiswara terkonsentrasi pada kurikulum. Namun demikian kurikulum bukanlah penentu utama. Masalah yang paling besar di hadapi bangsa ini sesungguhnya bukan hanya masalah kurikulum, namun adalah masalah kesadaran dan lemahnya kesadaran untuk berprestasi, kesadaran untuk sukses, kesadaran untuk meningkatkan SDM, kesadaran untuk meningkatkan kompetensi diri, maupun kesadaran untuk berbuat yang terbaik.

e. Anggaran.

Setidaknya ada dua hal yang menyebabkan timbulnya perhatian yang besar pada keuangan yaitu, Pertama, keuangan temasuk kunci penentu kelangsungan dan kemajuan lembaga pendidikan. Kenyataan ini mengandung konsekuensi bahwa program-program pembaruan atau pengembangan pendidikan dan pelatihan bisa gagal dan berantakan manakala tidak didukung oleh dana yang memadai. Kedua, anggaran dari pemerintah terbatas, jadi perlu pemikiran kreatif pemimpin mencari 
dana untuk pengembangan pendidikan dan pelatihan kedepan. Sumber anggaran BPSDM Provinsi Jambi berasal dari APBD Provinsi Jambi dan Kontribusi Peserta diklat.

2. Lingkungan Eksternal BPSDM Provinsi Jambi

a. Stakeholder

BPSDM perlu menangani hubungan dengan pemerintah kabupaten/kota sebagai stakeholder dan OPD di lingkup provinsi Jambi. Mengingat kabupaten/kota memiliki peranan yang sangat penting terhadap keberadaan, keberlangsungan bahkan kemajuan BPSDM. Salah satu parameter penentu keberhasilan lembaga pengembangan sumber daya manusia ini adalah menerima peserta untuk mengikuti programprogram diklat yang sudah direncanakan, atau menggunakan tenaga assesor untuk uji kompetensi baik yang dilakukan di BPSDM Provinsi Jambi atau diluar BPSDM Provinsi Jambi.

b. Pesaing

Pesaing akan melakukan berbagai cara memenangkan persaingan. Pesaing BPSDM provinsi Jambi antara lain adalah sebagai berikut:

Tabel 4

Pesaing BPSDM Provinsi Jambi

\begin{tabular}{|c|c|c|}
\hline Provinsi Jambi & Regional & Nasional \\
\hline OPD lain yang menyelenggarakan diklat tehnis. & - $\quad$ BPSDM Reg. Bukit Tinggi & - $\quad$ LAN RI Jakarta \\
\hline - $\quad$ LPMP & - $\quad$ LAN RI Aceh & - $\quad$ LAN RI Bandung \\
\hline - $\quad$ Bapelkes & & - $\quad$ BPSDM Kemendagri Jakarta \\
\hline - Kabupaten/kota yang mempunyai sarana diklat & & \\
\hline
\end{tabular}

Sumber: BPSDM Prov. Jambi 2018

c. Aturan-aturan terkait

Peraturan yang terlalu cepat berubah mengharuskan penyelenggaraan penddidikan dan pelatihan di BPSDM Provinsi Jambi serta pelaksanaan uji kompetensi bagi aparatur sipil negara cepat menyesuaikan program-programnya. Bila lembaga diklat ingin berhasil dan maju, hampir bisa dipastikan salah satu faktor keberhasilan adalah keterlibatan instansi pengirim dari kabupaten/kota maupun dari OPD di Provinsi Jambi, disamping itu penting untuk membangun jejaring kerja dan kepercayaan dengan stakeholder.

\section{Analisis SWOT BPSDM Provinsi Jambi}

SWOT adalah singkatan dari strength, weakneses, Opportunities and Threats (kekuatan, kelemahan, peluang dan ancaman). Analisis SWOT sudah menjadi alat yang umum digunakan dalam perencanaan strategis pendidikan, namun ia tetap merupakan alat yang efektif dalam menempatkan potensi institusi. SWOT dapat dibagi kedalam dua elemen - analisa internal yang berkonsentrasi pada prestasi institusi itu sendiri, dan analisa lingkungan eksternal (Edward Sallis, 2012).

1. Identifikasi Faktor Internal dan Eksternal BPSDM Prov. Jambi.

Tabel 5

Matrik Faktor Lingkungan Internal Dan Eksternal BPSDM Prov. Jambi INTERNAL
Kekuatan
1. Tersedianya pengelola diklat Aparatur yang sudah memiliki sertifikat MOT dan TOC
2. Tersedianya tenaga widyaiswara (18 orang)
3. Tersedianya tenaga asessor yang profesional (12 orang)
4. Tersedianya Sarpras Diklat yang memadai
5. Memiliki akreditasi lembaga
6. Hasil-hasil penyelenggaraan diklat Aparatur yang selama ini telah dilaksanakan.
7. Hasil-hasil asesmen dan uji kompetensi yang telah dilaksanakan

\footnotetext{
Peluang

1. Undang-Undang ASN mewajibkan ASN mengikuti diklat dalam rangka meningkatkan kompetensi.

2. Tuntutan tentang Standar pelayanan minimal (SPM) dalam Pelayanan publik

3. Kebijakan kepegawaian secara nasional yang mensyaratkan diklat sebagai bagian sistem pembinaan pegawai;

4. kabupaten/kota bisa diajak kerjasama diindikasikan dengan kerjasama penyelenggaraan diklat dengan sistem pola kemitraan;

5. Minat yang tinggi kabupaten/kota mengirimkan PNS nya untuk mengikuti diklat teknis/fungsional/
} 


\section{Kelemahan}

1. Belum optImalnya pemberdayaan diklat

2. Kurangnya pemahaman proses manajemen pengembangan SDM diindikasikan dengan masih lemahnya koordinasi baik internal maupun eksternal

3. Belum optimalnya TI untuk publikasi

4. Belum tersedianya master asessor ;

5. Belum terisinya jabatan Widyaiswara utama

6. Belum memiliki akreditasi A

7. Belum tersedianya sistem dan prosedur kerja yang baku dalam pengelolaan diklat Aparatur kepemimpinan

6. semakin meningkatnya kepercayaan kabupaten/kota untuk melakukan asesmen dan uji kompetensi di BPSDM Provinsi Jambi.

Ancaman

1. Situasi kondisi politik nasional dan lokal (dalam komitmen pengembangan SDM Aparatur);

2. Komitmen pengembangan dan peningkatan kualitas SDM berupa anggaranbelum sesuai (dibawah standar) dengan kektentuan SE. MENDAGRI.

3. terbatasnya penyelenggaraan Diklat Teknis/Fungsional/kepemimpinan;

4. belum bisa menyelenggarakan diklat kepemimpinan Tk. II, diindikasikan dengan lembaga belum akreditasi A dan belum ada widyaiswara ahli utama.

\section{Analisis Faktor-Faktor Strategi Eksternal BPSDM Provinsi Jambi}

\section{Tabel 5}

\section{IFAS BPSDM Provinsi Jambi}

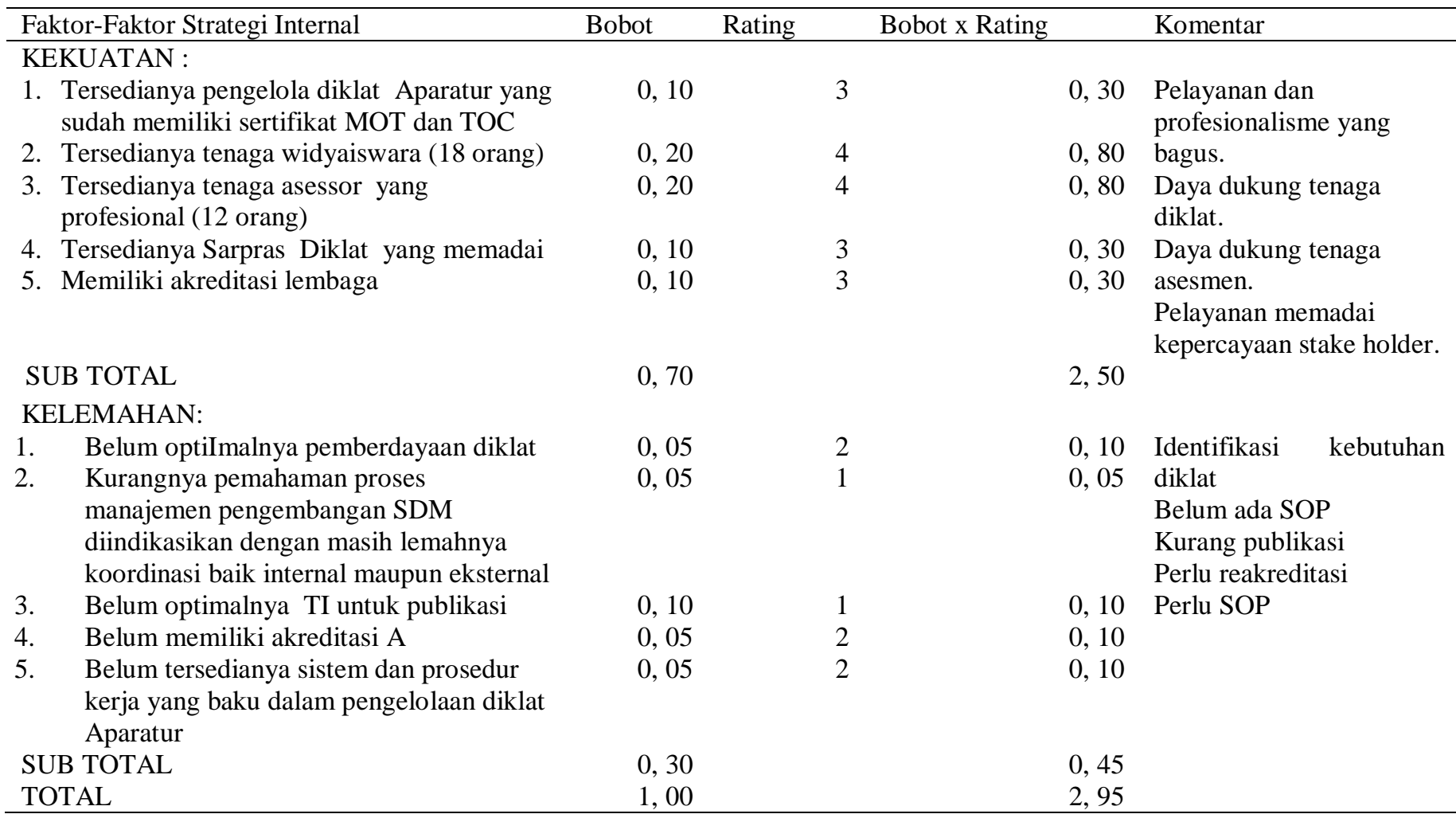

\section{Analisis Faktor-Faktor Strategi Eksternal BPSDM Provinsi Jambi}

Tabel 6

EFAS BPSDM Provinsi Jambi

\begin{tabular}{|c|c|c|c|c|}
\hline Faktor-Faktor Strategi Eksternal & Bobot & Rating & Bobot x Rating & Komentar \\
\hline \multicolumn{5}{|l|}{ PELUANG : } \\
\hline $\begin{array}{l}\text { 1. Undang-Undang ASN mewajibkan ASN } \\
\text { mengikuti diklat dalam rangka meningkatkan } \\
\text { kompetensi. }\end{array}$ & 0,15 & 4 & 0,60 & $\begin{array}{l}\text { anggaran diklat } \\
\text { meningkat }\end{array}$ \\
\hline $\begin{array}{l}\text { 2. Kebijakan kepegawaian secara nasional yang } \\
\text { mensyaratkan diklat sebagai bagian sistem } \\
\text { pembinaan pegawai; }\end{array}$ & 0,10 & 3 & 0,30 & $\begin{array}{l}\text { kebutuhan diklat } \\
\text { aparatur }\end{array}$ \\
\hline $\begin{array}{l}\text { 3. kabupaten/kota bisa diajak kerjasama } \\
\text { diindikasikan dengan kerjasama }\end{array}$ & 0,15 & 3 & 0,45 & $\begin{array}{l}\text { hubungan dengan } \\
\text { stake holder }\end{array}$ \\
\hline
\end{tabular}


kemitraan;

4. Minat yang tinggi kabupaten/kota mengirimkan PNS nya untuk mengikuti diklat teknis/fungsional/ kepemimpinan

5. Semakin meningkatnya kepercayaan kabupaten/kota untuk melakukan asesmen dan uji kompetensi di BPSDM Provinsi Jambi.

SUB TOTAL

ANCAMAN :

1. Situasi kondisi politik nasional dan lokal (dalam komitmen pengembangan SDM Aparatur);

2. Komitmen pengembangan dan peningkatan kualitas SDM berupa anggaran belum sesuai (dibawah standar).

3. Terbatasnya penyelenggaraan Diklat Teknis/ Fungsional/kepemimpinan;

4. Belum bisa menyelenggarakan diklat kepemimpinan Tk. II, diindikasikan dengan lembaga belum akreditasi A dan belum ada widyaiswara ahli utama.

5. Stake holder mengirim pesertanya ke luar Provinsi Jambi

SUB TOTAL

TOTAL
0,20
4
0,80 diklat berkontribusi
0,15
3
0,60 profesional
0,75
2,75
0,05
2
0,10 Perlu berhati-hati
0,05
1
0,05 Tantangan
0,10
1
0, 10 Anggaran rendah
0,05
1
0,05 Persyaratan
0,05
2
0,10 Kepercayaan
0,25
1,00
0,50
3,25

Setelah diperoleh nilai tertimbang dalam matriks evaluasi faktor internal dan eksternal, langkah selanjutnya adalah menyelesaikan kuadran model SWOT agar dapat menempatkan posisi BPSDM Provinsi Jambi. analisis faktor internal dan eksternal diatas, maka diperoleh data sebagai berikut:

1. Selisih antara kekuatan dan kelemahan (sebagai sumbu X dalam kuadran strategi) : $=\mathrm{S}-\mathrm{W}=2,50-0,45=2,05$

2. Selisih antara peluang dan tantangan (sebagai sumbu Y dalam kuadran strategi) : $=\mathrm{O}-\mathrm{T}=2,75-0,50=2,25$

Grafiknya dapat digambar sebagai berikut:

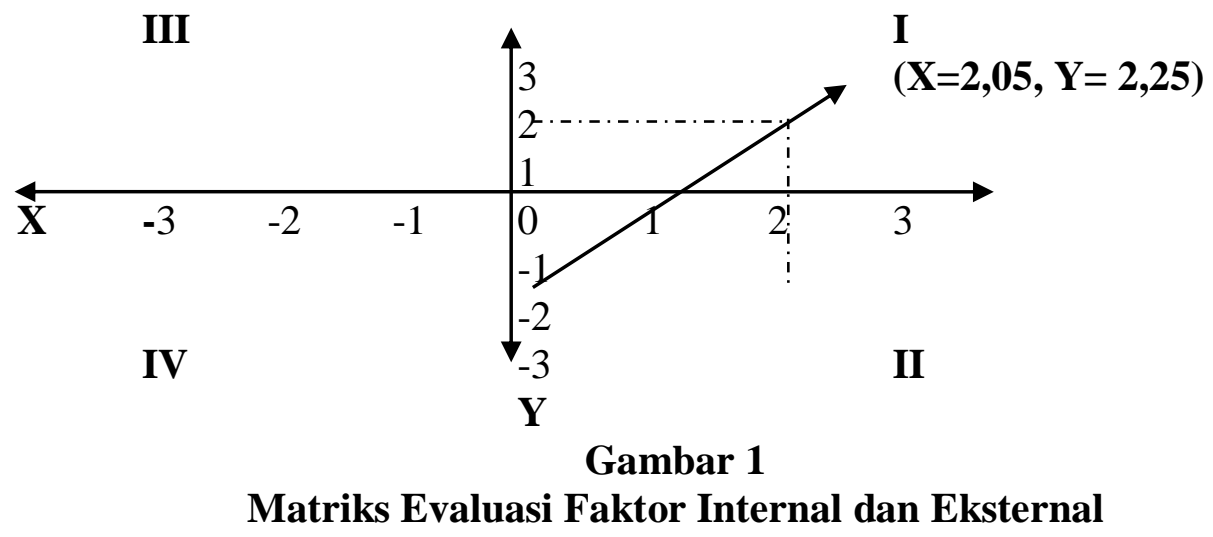

Penjelasan:

Grafik tersebut dapat terlihat posisinya pada kuadran I (positif, positif). Artinya posisi ini menandakan bahwa BPSDM Provinsi Jambi yang masih kuat dan berpeluang. Rekomendasi strategi yang diberikan adalah progresif, artinya organisasi dalam kondisi prima dan mantap sehingga sangat dimungkinkan untuk lebih melakukan ekspansi, memperbesar pertumbuhan dan meraih kemajuan secara maksimal.

\section{Strategi dari Hasil Analisis SWOT}


Alat yang dipakai untuk menyusun faktor-faktor strategis BPSDM Provinsi Jambi adalah matrik SWOT. Matrik ini dapat mengambarkan secara jelas bagaimana peluang dan ancaman eksternal yang dihadapi dapat disesuaikan dengan kekuatan dan kelemahan yang dimiliki.

\section{Analisis SWOT dan Faktor Kunci Keberhasilan BPSDM Provinsi Jambi MATRIK SWOT}

\begin{tabular}{|c|c|c|}
\hline & KEKUATAN & KELEMAHAN \\
\hline $\begin{array}{l}\text { Faktor-Faktor } \\
\text { Eksternal }\end{array}$ & $\begin{array}{l}\text { 1. } \begin{array}{l}\text { Tersedianya sistem dan prosedur } \\
\text { kerja yang baku dalam pengelolaan } \\
\text { diklat Aparatur; }\end{array} \\
\text { 2. } \begin{array}{l}\text { Tersedianya pengelola diklat } \\
\text { Aparatur yang sudah memiliki }\end{array} \\
\text { sertifikat MOT dan TOC } \\
\text { 3. Tersedianya tenaga widyaiswara (15 } \\
\text { orang) } \\
\text { 4. Tersedianya Sarpras Diklat yang } \\
\text { memadai } \\
\text { 5. Memiliki akreditasi lembaga }\end{array}$ & $\begin{array}{ll}\text { 1. } & \text { Belum optimalnya pemberdayaan } \\
\text { diklat } \\
\text { 2. } \\
\text { Kurangnya pemahaman proses } \\
\text { manajemen pengembangan SDM } \\
\text { diindikasikan dengan masih lemahnya } \\
\text { koordinasi baik internal maupun } \\
\text { eksternal } \\
\text { 3. } \\
\text { B. }\end{array}$ \\
\hline PELUANG & STRATEGI (SO) & STRATEGI (WO) \\
\hline $\begin{array}{l}\text { 1. Undang-Undang ASN } \\
\text { mewajibkan ASN mengikuti } \\
\text { diklat dalam rangka } \\
\text { meningkatkan kompetensi. }\end{array}$ & $\begin{array}{l}\text { 1. Penyusunan dan penyempurnaan } \\
\text { dalam pengelolaan diklat; } \\
\text { 2. Peningkatan koordinasi dengan } \\
\text { stakeholder }\end{array}$ & $\begin{array}{l}\text { Pemberdayaan diklat melalui } \\
\text { penyempurnaan dan pengelolaan } \\
\text { diklat dengan membuat SOP } \\
\text { pengelolaan diklat. }\end{array}$ \\
\hline $\begin{array}{l}\text { 2. Tuntutan tentang Standar } \\
\text { pelayanan minimal (SPM) dalam }\end{array}$ & $\begin{array}{l}\text { 3. Pendelegasian sebagian } \\
\text { kewenangan pengelolaan }\end{array}$ & $\begin{array}{l}\text { Tingkatkan koordinasi dengan } \\
\text { stakeholder dengan memanfaatkan TI. }\end{array}$ \\
\hline $\begin{array}{l}\text { Pelayanan publik } \\
\text { Kebijakan kepegawaian secara } \\
\text { nasional yang mensyaratkan } \\
\text { diklat sebagai bagian sistem } \\
\text { pembinaan pegawai; }\end{array}$ & $\begin{array}{l}\text { 7. SDM aparatur ke unit-unit kerja; } \\
\text { 4. Peningkatan performance dan } \\
\text { kinerja pengelola sumber daya } \\
\text { aparatur } \\
\text { 5. Penyusunan SPM Bidang }\end{array}$ & $\begin{array}{l}\text { Meningkatkan kerjasama dengan stake } \\
\text { holder dalam pelaksanaan diklat. } \\
\text { Memotivasi WI dengan menyediakan } \\
\text { sarpras untuk memperoleh jenjang WI } \\
\text { Utama }\end{array}$ \\
\hline $\begin{array}{l}\text { 4. kabupaten/kota bisa diajak } \\
\text { kerjasama diindikasikan dengan } \\
\text { kerjasama penyelenggaraan diklat } \\
\text { dengan sistem pola kemitraan; } \\
\text { 5. Minat yang tinggi kabupaten/kota }\end{array}$ & Kepegawaian. & $\begin{array}{l}\text { Menyusun SPM kepegawaian dan } \\
\text { organisasi, meningkatkan budaya } \\
\text { organisasi, dan komitmen dalam } \\
\text { upaya meningkatkan kinerja } \\
\text { organisasi }\end{array}$ \\
\hline
\end{tabular}
mengikuti diklat teknis/fungsional/ kepemimpinan

6. Semakin meningkatnya kepercayaan kabupaten/kota untuk melakukan asesmen dan uji kompetensi di BPSDM Provinsi Jambi.

ANCAMAN
1. Situasi kondisi politik nasional

Situasi kondisi politik nasional
dan lokal (dalam komitmen pengembangan SDM Aparatur);

2. Komitmen pengembangan dan peningkatan kualitas SDM berupa anggaran belum sesuai (dibawah standar) dengan ketentuan SE. MENDAGRI.

3. Terbatasnya penyelenggaraan Diklat Teknis/ Fungsional/ kepemimpinan;

4. Belum bisa menyelenggarakan diklat kepemimpinan Tk. II, diindikasikan dengan lembaga belum akreditasi A dan belum ada widyaiswara ahli utama.

\section{STRATEGI (ST)}

1. Menyusun rencana diklat berbasis kompetensi

2. Melakukan koordinasi dan konsultasi serta menyiapkan data terkait dan anggaran sebagai wujud komitmen organisasi untuk meningkatkan kualitas SDM.

3. Membuka peluang penyelenggaraan diklat melalui kontribusi perserta.

4. Menyiapkan sarpras dan tenaga pengajar berkualifikasi sesuai persyaratan penyelenggaraan diklat Kepemimpinan Tk. II

\section{STRATEGI (WT)}

1. Pelaksanaan diklat berbasis kompetensi sesuai dengan SOP.

2. Mengembangkan proses pembelajaran diklat melalui diklat e-learning.

3. Tingkatkan koordinasi dan kerjasama dengan stakeholder dalam rangka mewujudkan diklat-diklat melalui anggaran kontribusi.

4. Menyiapkan anggaran untuk mengirim WI mengikuti penjenjangan utama atau melalui diklat e-learning. 


\section{SIMPULAN}

Analisa SWOT dapat dilihat posisi kuadran BPSDM Provinsi Jambi berada di kuadran I (positif, positif). Artinya posisi ini menandakan bahwa BPSDM Provinsi Jambi kuat dan berpeluang. Rekomendasi strategi yang diberikan adalah progresif, artinya BPSDM Provinsi dalam kondisi prima dan mantap sehingga sangat dimungkinkan untuk terus melakukan ekspansi, dan memperbesar pertumbuhan, serta meraih kemajuan maksimal. Setelah melakukan analisa SWOT, BPSDM Provinsi Jambi diharapkan dapat menentukan perumusan strategi yang tepat, visi, misi, dan tujuan, sehingga diharapkan dapat meningkatkan mutu atau kualitas BPSDM Provinsi yang sesuai dengan perencanaan yang telah dilakukan, antara lain dengan melakukan sebagai berikut; Penyelenggaraan diklat berbasis kompetensi dan pelaksanaannya sesuai dengan SOP; Mengembangkan proses pembelajaran diklat melalui diklat e-learning; Meningkatkan koordinasi dan kerjasama dengan stakeholder melalui IT dalam rangka mewujudkan diklat-diklat menggunakan anggaran kontribusi; Menyiapkan sarana dan anggaran untuk mengirim Widyaiswara mengikuti diklat baik diklat peningkatan kompetensi widyaiswara, maupun mengikuti diklat peningkatan penjenjangan, dan ; meningkatkan sarana dan prasarana diklat dan penunjangnya.

\section{DAFTAR PUSTAKA}

Adisetiawan, R., 2017, Performance Mahasiswa Fakultas Ekonomi Universitas Batanghari, Jurnal Ilmiah Universitas Batanghari, 14(3), 1-10

Adisetiawan, R., 2016, Faktor yang Mempengaruhi Lulusan SMA dalam Memilih Fakultas Ekonomi Universitas Batanghari, Jurnal Ilmiah Universitas Batanghari, 16(3), 1-11

Barney, Jay.B, and William.S Hesterly. 2012. Strategic Management and Competitive Advantage Third Editio. Pearson Prentice Hall. United States of America.

Buchory, Herry Achmad \& Djaslim Saladin. 2010. Manajemen Pemasaran. Bandung: Linda Karya.

Engkoswara dan Aan Komariah. 2010. Administrasi Pendidikan. Bandung; Alfabeta.

Rangkuti, Freddy,. 2015. Analisis SWOT: Tehnik Membedah kasus Bisnis. Jakarta. Gramedia Pustaka Utama.

Ifediora Christian Osita, Idoko Onyebuchi R. and Nzekwe Justina. 2014. Organization's stability and productivity: the role of SWOT analysis an acronym for strength, weakness, opportunities and threat, International Journal of Innovative and Applied Research, Volume 2, Issue (9): 23- 32.

Jauch, L.R. dan Glueck, W.R. 1997. Manajemen Strategis dan Kebijakan Perusahaan, Edisi IV, Erlangga, Jakarta.

Jauch, Lawrence. R dan Glueck, William. 1998. Manajemen Strategis dan Kebijakan Perusahaan. Terjemahan Murad dan Henry Sitanggang. Penerbit Erlangga. Jakarta.

LAN RI. Peraturan Kepala Lembaga Administrasi Negara Nomor: 13 Tahun 2011.

LAN RI. PERKALAN NO. 20 TAHUN 2015 TTG PEDOMAN DIKLATPIM TK IV.

Lestari, Endah Prapti. 2011. Pemasaran Strategik: Bagaimana Meraih Keunggulan Kompetitif. Edisi Pertama. Yogyakarta: Graha Ilmu.

Maisah, 2016. Manajemen Stratejik dalam Perspektif Pendidikan Islam. Jambi. Media Salim Indonesia.

Michael A. Hit, R.Duane Ireland, Robert E. Hoskisson. 2001. Manajemen Strategis: Daya Saing dan Globalisasi; Konsep, Jakarta: Salemba Empat.

Nwachukwu Prince Ololube, Fidelis Aiya, Oboada Alafonye Uriah. Dennis Ogutum Ololube. 2016. Strategic Planning: A Universal Remedy for the Successful Management of 21st Century University Education (UE), Journal of Management, 6(3), 76-88 DOI: 10.5923/j.mm.20160603.03. Published online at http://journal.sapub.org/mm Copyright (c) 2016 Scientific \& Academic Publishing.

Pearce, John A, and Richard B Robinson. 2013. Strategic Management: Planning for Domestic \& Global Competition. Thirteenth Edition, McGraw-Hill Companies, Inc., New York.

Rais, Sasli, dan Wahkyudin. 2009. Pengembangan Pegadaian Syariah di Indonesia dengan analisis SWOT. Jurnal Pengembangan Bisnis dan Manajemen, IX(14).

Siagian, Sondang P,. 2005. Manajemen Stratejik. Jakarta. Bumi Aksara.

Sallis, Edward., 2012. Total Quality Management in Education (Manajemen Mutu Pendidikan). Yogyakarta; IRCiSoD. 


\section{Lailatul Isnaini, Musfarita Affiani}

Thompson, A Arthur, A.J. Strickland, and E. John Gamble. 2010. Crafting and Executing Strategy The Quest for Competitive Advantage: Concept and Cases, Seventeenth Edition, The McGraw Hill company, USA.

Wheelen, L Thomas, and J.David Hunger. 2012. Strategic Management and Business Policy Concepts and Cases. Eleventh Edition. Prentice-Hall International USA. 